\title{
Obituaries
}

48. "Valedictory Address to the Medico-Chirurgical Society of Edinburgh." By A. Logan Turner, President, M.D., LL.D., F.R.S.E., Edin. Med. Journ., I930.

49. "Some Impressions that Remain." By A. L. Turner. Journ. Lar. and Otol., 1936.

A. Brown Kelly.

\section{ARTHUR WELLESLEY SANDFORD}

\section{Born I 858}

SANDFORD joined the writer, Macintyre and Milligan in maintaining the Journal of Laryngology, Rhinology and Otology at a time when the demand for it was insufficient to allow of it being carried on without the financial support and active co-operation of those few who believed in it and handed it on with all goodwill to their successors and a writer in the Times has signalized his many remarkable qualities. In the little intimate circle of his colleagues who with him kept the Journal of Laryngology going his arrival was always a cause for rejoicing. When difficulties or differences of opinion marred the working of the little syndicate Sandford's beaming countenance shed sunlight on the proceedings and his musical persuasive utterances smoothed out all wavelets of dissension. Unhappily his colleagues have nearly all passed away but as long as they survived they retained a warm place in their hearts for Arthur Sandford.

JAMEs DUndaș-Grant. 